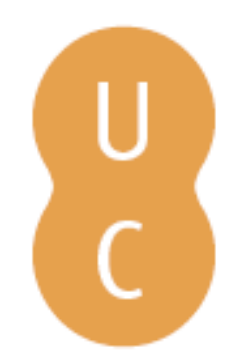

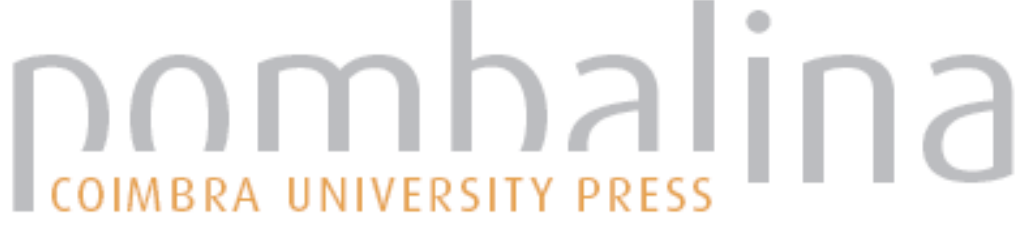

\section{De modelos e afinidades: Balzac, Dumas e Camilo}

Autor(es): $\quad$ Oliveira, Paulo Motta

Publicado por: Imprensa da Universidade de Coimbra

URL

persistente: URI:http://hdl.handle.net/10316.2/38713

DOI: $\quad$ DOI:http://dx.doi.org/10.14195/978-989-26-1164-8_36

Accessed : $\quad$ 26-Apr-2023 15:16:34

A navegação consulta e descarregamento dos títulos inseridos nas Bibliotecas Digitais UC Digitalis, UC Pombalina e UC Impactum, pressupõem a aceitação plena e sem reservas dos Termos e Condições de Uso destas Bibliotecas Digitais, disponíveis em https://digitalis.uc.pt/pt-pt/termos.

Conforme exposto nos referidos Termos e Condições de Uso, o descarregamento de títulos de acesso restrito requer uma licença válida de autorização devendo o utilizador aceder ao(s) documento(s) a partir de um endereço de IP da instituição detentora da supramencionada licença.

Ao utilizador é apenas permitido o descarregamento para uso pessoal, pelo que o emprego do(s) título(s) descarregado(s) para outro fim, designadamente comercial, carece de autorização do respetivo autor ou editor da obra.

Na medida em que todas as obras da UC Digitalis se encontram protegidas pelo Código do Direito de Autor e Direitos Conexos e demais legislação aplicável, toda a cópia, parcial ou total, deste documento, nos casos em que é legalmente admitida, deverá conter ou fazer-se acompanhar por este aviso.

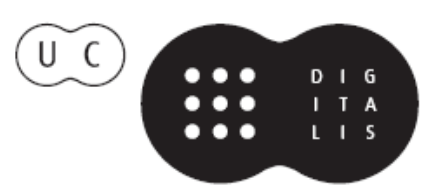


Paulo Motta Oliveira

Universidade de São Paulo

\section{DE MODELOS E AFINIDADES: \\ BALZAC, DUMAS E CAMILO}

\section{Um Balzac português}

É habitual e recorrente a aproximação entre Camilo e Balzac. Para apenas citarmos dois exemplos temporalmente distantes, lembremos de Alberto Pimentel e de Abel Barros Baptista, separados por quase um século. O primeiro, em O romance do romancista, livro que, apesar de inúmeros equívocos, é incontornável para os que estudam a obra do autor de Anátema, afirmou

O romance Onde está a felicidade? Apareceu em 1856. Literariamente, demarca a segunda maneira de Camilo como romancista.

O fecundo escritor principiou pelo romance de imaginação tenebroso e complicado (...) navegando no rumo explorado por Victor Hugo e Eugênio Sue (...)

Foi a leitura de Balzac, na Comédie humaine, que lhe sugeriu o caminho a seguir(...)?

Por sua vez criou outra "Comédia humana", a dos portugueses, a nossa (...).

Camilo introduziu, pois, em Portugal a escola de Balzac ${ }^{1}$

Quase um século depois, em Camilo e a revolução camiliana, encontramos

1 Pimentel, 1922, p. 191-2. 
Camilo foi o Balzac que a nossa literatura não teve, perdeu-se nele a oportunidade do Balzac português. Há quem pense que Camilo tinha mesmo condições pessoais para ser o Balzac português, e há quem suponha o contrário, mas o problema não está aí (...), o que sempre se lamenta é o lugar de um Balzac português que por causa de Camilo a nossa literatura desperdiçou. ${ }^{2}$

Aqui a ligação entre Balzac e Camilo é estruturada pela falta: o autor português poderia ter sido um Balzac, mas que não chegou a sê-lo, e com ele se perdeu a possibilidade de que outro escritor ocupasse esse lugar.

Entre esses dois livros muitos foram os contatos apontados pela crítica entre o autor de Anátema e o de Ilusões perdidas, desde títulos como Cenas inocentes da comédia bumana, até procedimentos similares, como a tentativa de retratar o funcionamento e as mazelas das sociedades em que viveram.

De fato essa aproximação já havia sido tecida pelo próprio Camilo que, em seus livros, não deixaria de apontar proximidades e afastamentos entre ele e o autor francês. Opto por dois exemplos, dos muitos possíveis, em momentos cruciais da carreira do escritor.

Em Amor de Perdição, de 1862, quando está a se referir à falta de dinheiro de Simão, o narrador escreve

Deviam de ocorrer-lhe ideias aflitivas, que os romancistas raras vezes atribuem aos seus heróis. Nos romances todas as crises se explicam, menos a crise ignóbil da falta de dinheiro. Entendem os novelistas que a matéria é baixa e plebeia. O estilo vai de má vontade para coisas raras. Balzac fala muito em dinheiro; mas dinheiro a milhões: não conheço, nos cinquenta livros que tenho dele, um galã num entreato da sua tragédia a cismar no modo de arranjar uma quantia com que um usurário lhe lança, desde a casa do juiz de paz a todas as esquinas, donde o assaltam o capital e o juro de oitenta por cento. Disto é que os mestres em romances se escapam sempre.(...)

Pois eu já lhes fiz saber, leitores, pela boca de mestre João, que o filho do corregedor não tinha dinheiro. ${ }^{3}$

\footnotetext{
2 Baptista, 1988, p. 18.

3 Castelo Branco, 1984, p. 448 (atualizou-se a grafia nas citações).
} 
Se aqui aponta uma diferença entre ele e Balzac - por mais que indique que é um leitor da obra deste -, em outro trecho de 1879, ou seja quase vinte anos depois, afirmaria a sua filiação à escola do autor de A comédia humana. No irônico e brilhante prefácio à segunda edição de Eusébio Macário, após indicar que considera esse seu livro como "o mais banal, mais oco e mais insignificante romance que ainda alinhavei para as fancarias da literatura de pacotilha”, escreve:

Cumpre-me declarar que eu não intentei ridicularizar a Escola Realista. Quando apareceram O Crime do Padre Amaro, O Primo Basílio e os romances de Teixeira de Queirós, admirei-os, e escrevi ingenuamente o testemunho da minha admiração. Creio que, hoje em dia, novela escrita doutro feitio, não vinga. Eu não conhecia Zola e ainda agora apenas e escassamente o conheço de o ouvir apreciar a uma pessoa de minha família que me fez compreender a Escola com duas palavras: «É a tua velha Escola com uma adjetivação de casta estrangeira, e uma profusão de ciência compreendida na "Introdução aos três reinos". Além disso tens de pôr a fisiologia onde os românticos punham a sentimentalidade: derivar a moral das bossas, e subordinar à fatalidade o que, pelos velhos processos, se imputava à educação e à responsabilidade.» Compreendi, e achei que eu, há vinte e cinco anos, já assim pensava, quando Balzac tinha em mim o mais inábil e ordinário dos seus discípulos. ${ }^{4}$

Gostaria de refletir sobre o quão inadequada é essa aproximação entre Camilo e Balzac, e de como ela acaba por mascarar alguns problemas importantes, gerando alguns equívocos na avaliação do escritor português. Ou, em outros termos, gostaria de mostrar que ao aceitarmos os depoimentos do pouco confiável narrador camiliano estamos a realizar um procedimento provavelmente agradável para o autor, mas que oculta laços mais fortes e consistentes, criando uma falsa genealogia. Para tanto julgo que é importante inicialmente clarificar o estatuto que esses dois escritores possuíam no Portugal das décadas de 50 e 60 do século XIx, aspecto que, parece-me, ainda não foi suficientemente analisado pela crítica.

\footnotetext{
4 Castelo Branco, 1988, p. 463-4.
} 
Camilo publicou 12 romances na década de 50 - sendo que a metade desses teve uma segunda edição até 1860 - e outros 30 na década de 60. Nesse mesmo período de 20 anos Balzac teve apenas 10 narrativas traduzidas, como podemos ver na relação abaixo, elaborada a partir de A tradução em Portugal de A. A. Gonçalves Rodrigues.

$\begin{array}{ll}\text { Ano } & \text { Obra } \\ 1850 & \text { A bolsa } \\ 1855 & \text { O filho amaldiçoado } \\ 1856 & \text { A mensagem } \\ 1858 & \text { A Serafita } \\ 1859 & \text { A estalagem vermelha } \\ 1861 & \text { A amante fictícia } \\ 1867 & \text { O ambicioso por amor } \\ 1869 & \text { A duquesa de Langeais } \\ 1869 & \text { A missa do ateu } \\ 1869 & \text { Uma paixão no deserto }\end{array}$

Essas narrativas, hoje praticamente desconhecidas, estão muito longe daquilo que, atualmente, é considerado como o centro da obra do autor de A comédia bumana. A primeira obra significativa de Balzac a ser traduzida em Portugal foi Eugênia Grandet, o que só viria a ocorrer em 1873, ou seja 40 anos depois de ter sido lançada na França. Assim, se de fato Camilo tinha cinquenta livros de Balzac, como afirma o narrador de Amor de perdição, eles não poderiam ser traduções portuguesas. Ele só teria condições de conhecer as obras significativas do autor de Ilusões Perdidas se as lesse na sua língua original.

O confronto entre o número de edições de Camilo e de Balzac nas décadas de 50 e 60 mostra que os dois ocupavam, em Portugal, posições muito diversas. Em relação ao segundo desses autores, referências ao número de traduções das narrativas de dois outros escritores poderão clarificar ainda mais o papel pouco significativo que ele ocupava no cenário das obras traduzidas em Portugal. Esses dois autores são, em princípio, de estatuto bastante diverso. O primeiro trata-se de um escritor com grande importância no período, traduzido praticamente em 
todo o mundo: Eugênio Sue. Já o segundo, mesmo na época, possuía pouca penetração na França, mas, talvez por escrever romances ligados com os valores cristãos, teve uma trajetória significativa em Portugal: Émile Souvestre.

\begin{tabular}{|c|c|c|c|c|c|c|c|c|c|c|c|c|c|c|c|c|c|c|c|c|c|}
\cline { 2 - 17 } \multicolumn{1}{|c|}{} & \multicolumn{10}{|c|}{ Anos 50} & \multicolumn{10}{c|}{ Total } \\
\hline Ano & 50 & 51 & 52 & 53 & 54 & 55 & 56 & 57 & 58 & 59 & 60 & 61 & 62 & 63 & 64 & 65 & 66 & 67 & 68 & 69 & \\
\hline Sue & 8 & 8 & 1 & 0 & 8 & 1 & 6 & 3 & 5 & 0 & 0 & 5 & 0 & 2 & 0 & 1 & 4 & 2 & 4 & 0 & 58 \\
\hline Souvestre & 0 & 0 & 1 & 1 & 0 & 2 & 3 & 1 & 4 & 2 & 2 & 1 & 1 & 1 & 6 & 2 & 3 & 0 & 2 & 1 & 33 \\
\hline
\end{tabular}

Se aos dados numéricos acima, acrescentarmos o fato que algumas das narrativas traduzidas de Sue e de Souvestre constituiam longos romances - como, por exemplo, Os mistérios de Paris do primeiro e O rei do mundo - bistória do dinbeiro e da sua influência do segundo - podemos ver como, no universo das obras traduzidas em Portugal, Balzac era um escritor praticamente irrelevante.

Ora, tudo que até aqui apontamos parece indicar que, pelo menos para o Portugal do período em que Camilo se lança como romancista, uma aproximação com Balzac faria pouco sentido. Este era quando muito um nome, mas não um autor efetivamente lido, pelo menos pelo público que só lia em português. Aquele, por seu turno, desde o início de sua carreira como romancista tinha uma presença significativa no mercado editorial português.

Em 1890, quando Alberto Pimentel lança a sua biografia sobre o autor de Anátema, uma comparação entre os dois já seria mais cabível, não só porque a partir de meados da década de 70 a tradução das obras de Balzac foi constante - ele teve, entre 1873 e 1886, 27 traduções, e outras 16 entre 1887 e 1889 mas principalmente pois foi no fim da década de 80 que foram, com enorme defasagem em relação aos originais, traduzidas algumas das grandes obras do autor: em 1887, Ilusões Perdidas; no ano seguinte Esplendores e misérias das cortesãs e em 1889, O tio Goriot. Podemos entender o motivo do trecho com que abrimos esse artigo: naquela época Balzac ganhava, enfim, uma visibilidade no país, e podia ser lido em português.

Mas o que teria levado Camilo a se vincular, por oposição ou por semelhança, ao criador de Vautrin? 
Se é difícil responder a essa pergunta de forma categórica, creio que um retorno ao segundo trecho que dele citamos - o prefácio a Eusébio Macário - poderá permitir que formulemos uma hipótese pelo menos plausível. Nesse texto, como notamos, Camilo trabalha com algumas dicotomias, criando dois polos: para usarmos os seus termos, de um lado a "Escola", e do outro a sua "velha Escola". Numa primeira leitura poderíamos pensar que se trata de uma oposição entre a sua forma de escrever, em que, como afirma no prefácio à quinta edição de Amor de Perdição, também ele de 1879, "as dores da alma podiam ser descritas sem grande desaire da gramática e da decência”, e a dos novos escritores que, ainda deste último prefácio, espremem "o pus de muitas escrófulas na face do leitor." Se essa oposição também está presente no paratexto de Eusébio Macário, parece-me que há uma outra, implícita para os leitores da época, mas que hoje precisaria ser explicitada para ser melhor entendida.

Camilo cria, de fato, duas escolas no texto, contrapondo a sua obra, que seria fruto de um "inábil e ordinário" discípulo de Balzac, à de outros escritores, como Eça e Teixeira de Queirós, que seguiriam Zola. Bem, já apontamos o quão pouco as obras de Balzac eram conhecidas para os leitores que não as podiam ler em francês. Esses, em 1879, das suas grandes obras, teriam tido acesso apenas a Eugênia Grandet.

Bem outra era a situação de Zola nesse momento. Estava então começando a ocorrer o boom das traduções de suas obras em Portugal. Após ter o seu primeiro livro traduzido em 1877 - O regabofe que foi publicado de forma incompleta em uma coleção intitulada Biblioteca para homens - teve um outro traduzido no ano seguinte, 7 em 1879 e 10 em 1880. Ele era então o autor popular do momento. Assim, parece-me, Camilo não está apenas opondo a velha à nova escola, mas uma literatura de certa forma culta, a uma outra popular, de fácil acesso. Afinal se qualquer leitor poderia ter acesso a obras centrais do autor de Germinal recém-traduzidas para o português, parece que apenas aqueles que dominavam a língua francesa poderiam ler a maior parte dos romances do autor de Pai Goriot. Se conjugarmos o que vem dito no texto que estamos a analisar com o já referido prefácio a Amor de perdição creio que nossa hipótese se reforça: tudo, na nova literatura lá descrita, é de baixa qualidade. Numa oposição cerrada entre o passado

5 Castelo Branco, 1984, p. 381-2. 
e o presente, ele enumera: "Usava-se então a retórica de preferência ao calão. O escritor antepunha a frequência de Quintiliano à do "Colete Encarnado". A gente imaginava que os alcouces não abriam gabinetes de leirtura e artes correlativas."

Assim, ao lado do ataque à nova escola, Camilo pretende também situar-se no campo da literatura séria e culta, contrapondo-se a Zola e a seus seguidores portugueses. De certa forma podemos supor que foi bem sucedido, e acabou por construir uma aproximação entre a sua obra e a do autor de Ilusões Perdidas. Mas teve, ele não o poderia saber, de pagar um caro preço por isso. Ele não coube dentro do modelo a que tentou se vincular.

\section{Um escritor sem método?}

Teófilo Braga, em As modernas ideias da literatura portuguesa, livro publicado dois anos depois da morte de Camilo, tece alguns comentários que podem ser úteis para a nossa análise.

Na literatura portuguesa contemporânea, Camilo Castelo Branco é a mais poderosa organização estética, exercida em uma prolongada e contínua idealização, refletindo na sua obra todo o estado moral de uma época perturbada por falta de uma doutrina. Cabe-lhe a glória de ter criado um novo género literário - o romance burguês, fundado no conflito dos interesses domésticos e nos tipos subalternos da personalidade humana. A sua longa atividade exerceu-se sem plano, segundos as sugestões de um temperamento impressionável, obedecendo às correntes do meio social em que flutuava, sem se preocupar com o destino de suas concepções. ${ }^{7}$

A ideia de que faltava, a Camilo e à sua época, uma doutrina, e de que o escritor exerceu a sua atividade sem um plano será insistentemente repetida pelo historiador.

\footnotetext{
6 Castelo Branco, 1984, p. 381-2.

7 Braga, 1892, p. 240.
} 
Um pouco mais à frente, referindo-se ao conjunto da produção camiliana, afirma

O inventário bibliográfico de todas as suas produções acusa também a situação do escritor, que longe de poder exercer uma direção espiritual na sociedade portuguesa, obedeceu às necessidades materiais de cada dia pondo-se à mercê das exigências dos livreiros. Pelo nome dos editores se conhece muitas vezes a índole dos seus escritos; um F. Gomes da Fonseca exige livros religiosos; a empresa Comércio do Porto só paga romances da mais paradisíaca honestidade; a casa Moré propende para a preferência aos romances históricos; Chardron explora o escândalo, os livros de polémica. ${ }^{8}$

Este autor que, para Teófilo, vendeu a sua pena aos mais diferentes editores, não teria conseguido nem mesmo coordenar a obra que escreveu:

Teria sido bom, que o próprio artista, ao fim de 45 anos de atividade, lançasse uma vista geral à sua obra, e a coordenasse, ou segundo a concepção sintética do seu espírito ou segundo as modificações da sua própria existência. Camilo Castelo Branco não podia proceder assim; a espontaneidade de impressionista não o deixava seguir um plano de vida, nem prosseguir uma ideia fundamental na sua atividade?

O crítico, após fazer uma análise em que se mesclam o estudo da vida e das obras de Camilo, irá, no fim capítulo dedicado ao escritor, tecer algumas considerações interessantes para o raciocínio que aqui estamos desenvolvendo. Após considerar que o tempo acabaria por fazer com que se separasse, na vasta produção camiliana, as obras realmente importantes daquelas sem relevância, processo que já então estava a ocorrer com a obra de Walter Scott, aponta

E já que aludimos aos numerosos romances de Walter Scott, toda a sua obra, admirável nos detalhes, amesquinha-se pela falta de um pensamento geral,

\footnotetext{
8 Braga, 1892, p. 241-242.

9 Braga, 1892, p. 242.
} 
um plano, uma síntese filosófica, de que fosse a laboriosa realização. No meio da grande construção da Comédia humana, Balzac compreendeu a dispersão em que ia malbaratando o seu génio (...) reconhecendo a necessidade de uma tese fundamental. ${ }^{10}$

Essa tese fundamental, Teófilo a explica considerando

Os estudos biológicos (...) vieram revelar a Balzac o elemento generativo para a criação e coordenação dos tipos dos seus romances. O homem individualmente igual a outro homem, é, segundo a conformação e adaptação social, tão diferenciado do seu semelhante como o lobo, o cão de gado, o lebreu e o cão de regaço entre si. Balzac reconheceu a ação profunda do meio social $(. .)^{11}$

Mais a frente, ainda nesse capítulo, o crítico ainda virá a aproximar a obra de Balzac da de Zola, considerando que também este, como o primeiro, criou a sua obra a partir de uma ideia central.

Não pretendo aqui discutir a forma como Teófilo analisa as obras de Balzac e Zola, mas notar que ao se deter especialmente na obra do primeiro destes ao finalizar o seu capítulo sobre Camilo, ele acaba por efetuar um processo de rebaixamento do autor que está estudando. Faltou a este uma tese fundamental, algo que o autor francês soube ter, coordenando de forma consistente a sua obra.

Creio que esse livro de Teófilo - autor que teve a sua obra cada vez mais menosprezada conforme o século xx foi avançando, mas que apresentou algumas hipóteses que acabaram por ser incorporadas em várias das histórias literárias posteriores - é um bom exemplo para mostrar os efeitos perniciosos de uma ligação tão estreita entre Camilo e Balzac. Comparada com A comédia bumana a obra de Camilo será sempre falha, incompleta, desestruturada. Isso, parece-me, é realmente inegável. Mas, creio, essa imagem da escrita camiliana acaba por ser produzida não por um problema intrínseco que ela possua, mas pela inadequação do modelo que é utilizado para a comparação. Camilo - excetuando-se alguns títulos, poucos personagens que retornam em mais de um romance, e a

10 Braga, 1892, p. 280-281.

11 Braga, 1892, p. 279-280. 
preocupação de analisar em sua obra aspectos da sociedade de seu país - pouco tem de Balzac. Poderia aqui tentar demonstrar essa hipótese confrontando com mais cuidado as obras dos dois escritores, mas isso extrapolaria em muito o espaço que temos, e acabaria por nos afastar do que é o segundo objetivo deste ensaio: o de mostrar o que me parece ser uma efetiva proximidade, e de como ela pode lançar luz sobre aspectos importantes da forma de narrar camiliana. Assim me contento em apresentar um breve e certeiro comentário de Teixeira de Pascoaes, presente em O penitente: "Onde ela [a tua cara, Camilo] se destaca é em quase toda a tua obra. Como Dostoiévski, não pertences à classe dos grandes escritores invisíveis, Balzac e Victor Hugo, por exemplo."12.

Como vemos, aqui Camilo e Balzac são colocados em dois polos opostos, e representam, para Pascoaes, duas formas diversas de construção literária. Enquanto o escritor francês, mesmo que seu narrador teça comentários e juízos de valor, jamais aparece como um indivíduo que se situa entre o leitor e sua obra, o mesmo não ocorre com o autor de Anátema. Retomemos aqui Alberto Pimentel, e o que afirmou no prefácio ao seu O romance do romancista:

Isto que vai ler-se é o drama de uma alma superior, em grande parte extraído dos seus próprios livros. A vida de Camilo abunda pitorescamente em lances de boa e má fortuna. O mesmo é ler este escritor que coordenar mentalmente o romance da sua existência. O que eu fiz apenas foi dar à emoção produzida pela sua obra a fixação cronológica de uma biografia. Algumas investigações que me pertencem, derivaram naturalmente do desejo de substituir as reticências e preencher as lacunas que os seus livros, escritos sem a preocupação de uma autobiografia, opunham à justa curiosidade do leitor. ${ }^{13}$

Se certamente Pimentel parte aqui de uma premissa equivocada - a de que seria possível confiar no narrador camiliano - mostra a importância que esse ente, que para muitos de seus leitores se confundia com o próprio romancista, possuía na produção camiliana. Pascoaes, na mesma biografia já citada, afirma:

\footnotetext{
12 Pascoaes, 1985, p. 30.
}

13 Pimentel, 1890. p. 5. 
"Não é ele [Camilo] o único herói das suas novelas realmente humano e universal? Os outros representam simples caracteres (...)."14

Creio que essas breves referências já mostram que por mais que possamos encontrar algumas similitudes entre as obras de Camilo e Balzac, essas obras estruturalmente são muito diversas. Na do autor português, se algo dá unidade a seus vários e diversos romances, não é uma ideia síntese, ou um plano estruturador. É uma voz que parece encarnar a do próprio romancista, e que vamos encontrando, de forma mais ou menos explícita, nos seus vários romances e ainda em textos que poderiam parecer memorialísticos, como Memórias do Cárcere e No Bom Jesus do Monte. A presença dessa voz acaba por produzir uma série de efeitos, de que já trataremos, que ainda mais afastam a obra de Camilo da de Balzac. Mas, devemos salientar, a aproximam da de um outro escritor.

\section{Entre o livro e o leitor}

Aqueles que conhecem alguns de meus artigos, sabem que um dos temas que tenho, de diferentes formas, visitado nos últimos anos, é o da posição quase à margem do cânone que ocupa Camilo, de que talvez o melhor exemplo recente seja o de ele nem chegar a ser citado no prefácio ao volume sobre o romantismo da História crítica da literatura portuguesa, exemplo que poderia ser aqui corroborado por inúmeros outros, como a meia frase que lhe dedica Eduardo Lourenço em "Da literatura como representação de Portugal", ou a forma como a sua obra é referida, entre outros, por Tengarrinha e Óscar Lopes. ${ }^{15}$ Essa situação, de um escritor quase à margem, é exatamente a que possui, dentro da literatura francesa, Alexandre Dumas, autor que apesar de seu enorme sucesso enquanto vivo e do fato de continuar, até hoje, a ser republicado, precisou esperar o seu bicentenário para que, finalmente, os seus restos mortais fossem para o Panteão, ao lado de outros que lá chegaram bem mais rápido, como Victor Hugo, que, como sabemos, lá foi enterrado quando morreu.

\footnotetext{
14 Pascoaes, 1985, p. 99.

15 Lopes, 1991; Lourenço, 1978; Reis, Pires, 1999; Tengarrinha, 1973.
} 
As proximidades entre Dumas e Camilo podem ser reforçadas se pensarmos nas traduções de narrativas do primeiro em Portugal, o que mostra que ele ocupava, no país, entre os autores traduzidos, o mesmo papel de preponderância que Camilo ocupava entre os autores nacionais. Dumas teve 107 traduções nos anos 50 e outras 63 nos 60 .

\begin{tabular}{|c|c|c|c|c|c|c|c|c|c|c|c|}
\cline { 2 - 11 } \multicolumn{1}{c|}{} & 0 & 1 & 2 & 3 & 4 & 5 & 6 & 7 & 8 & 9 & Total \\
\hline Anos 50 & 13 & 19 & 12 & 14 & 9 & 9 & 12 & 9 & 3 & 7 & 107 \\
\hline Anos 60 & 15 & 5 & 7 & 5 & 3 & 6 & 12 & 3 & 4 & 3 & 63 \\
\hline
\end{tabular}

Também a sua trajetória editorial - autor de mercado e que escreve para o mercado - o aproxima de Camilo, acusado, como acabamos de ver, de vender a sua pena aos mais diferentes editores, independentemente das posturas políticas e editoriais que tivessem. Por sinal a falta de uma postura política clara do escritor português também encontra eco em Dumas. Não resisto aqui a referir a fuga deste para o exílio, quando Napoleão III subiu ao poder, afirmando publicamente que, como Victor Hugo, se exilava por motivos políticos, quando, na verdade, saía do país para fugir dos seus credores.

Mas, de fato, creio que a maior proximidade que podemos encontrar entre esses dois autores tão populares é que também Dumas é, pelo menos em parte de sua produção, um escritor não transparente. Certamente, se lermos apenas as suas grandes obras, como O conde de Monte Cristo ou Os três mosqueteiros, não veremos essa semelhança. Ela ocorre em uma série de outros livros, hoje quase totalmente esquecidos. Se confrontarmos, por exemplo, Pauline, Os irmãos corsos ou Gabriel Lambert, com os romances de Camilo, encontraremos no escritor francês alguns dos procedimentos que estão presentes nos romances camilianos: um narrador que se apresenta como o próprio autor e que muitas vezes escuta uma história que outro lhe conta; a reprodução de documentos - como cartas e diários - que comprovariam a veracidade da história contada; a pluralidade de vozes narrativas; a relação entre livros autobiográficos e obras ficcionais, que se comunicam como se possuíssem o mesmo estatuto. Todas essas características que já afirmei estarem presentes na produção camiliana ${ }^{16}$ parecem assim advir

16 Tratei desses aspectos da obra de Camilo em Oliveira, 2009. 
de um aproveitamento de estratégias já utilizadas por Dumas. Se não tenho como aqui desenvolver com mais cuidado essa comparação, cito apenas o exemplo de Gabriel Lambert, cuja primeira edição é de 1843, e que teve sua primeira tradução em Portugal cinco anos depois.

Veraneando em 1835, em Toulon, o narrador - que se assume como Alexandre Dumas - encontra um prisioneiro, um forçado, Gabriel Lambert, que lhe parece familiar, mas que ele não consegue lembrar em que momento havia, antes, conhecido. Quando, mais tarde, o forçado lhe envia um bilhete informando o nome que assumira na sociedade parisiense - o de visconde Henri de Faverne - o narrador se recorda de quem ele é, e conta ao leitor o que dele se lembrava. Após retornar a Paris encontra-se com um médico, o doutor Fabien, que cuidou do visconde após um duelo, e que anotou em uma espécie de livro de memórias todos os encontros que teve com Henri, anotações que o narrador reproduz no romance, e entre as quais encontramos a reprodução de várias cartas e mesmo um longo depoimento de Marie Granger, uma namorada de Henri que fora por ele abandonada. Por fim o narrador reproduzirá uma carta de um outro forçado, Rossignol, através da qual teremos acesso aos últimos lances da história de Gabriel Lambert.

O início do primeiro capítulo do romance já mostra, de forma clara, o estatuto dúbio com que essa narrativa quer se apresentar a seus leitores:

J'étais vers le mois de mai de 1835 à Toulon.

J'y habitais une petite bastide qu'un de mes amis avait mise à ma disposition. (...)

Je m'étais retiré là dans l'intention louable de travailler. J'avais dans la tête un drame bien intime, bien sombre, bien terrible, que je voulais faire passer de ma tête sur le papier.

Ce drame si terrible c'était Le Capitaine Paul ${ }^{17}$

Na edição que utilizo, organizada por Anne-Marie Callet-Bianco, é indicado que de fato Dumas foi para Toulon no período acima citado, o que foi narrado

17 Dumas, 2009, p. 31. 
no seu livro, publicado em 1840, Une année à Florence, e que, como sabemos, efetivamente ele lançou o Le Capitaine Paul em 1838. Ou seja, já na sua abertura a obra se apresenta com referências a episódios da vida de Dumas, aspectos que poderiam já ser conhecidos pelo leitor, o que reforçaria a sensação que estaríamos diante de um fato que efetivamente ocorreu, que foi utilizado pelo escritor para construir esse livro. Ele seria, assim, não propriamente o autor, mas o cronista de um acontecimento real.

O narrador não deixa, ainda, escapar as oportunidades de comprovar a veracidade da história que narra. Duas das cartas que reproduz - uma de Gabriel Lambert e outra de Rossignol - são copiadas, como é explicitamente referido nos dois casos, com os erros de ortografia que possuíam.

Como podemos notar, aqui encontramos vários procedimentos usuais nas narrativas camilianas. O livro de Dumas é composto por um narrador principal - que se confunde com o próprio autor - e que cede a narrativa a vários outros, reproduzindo, em sua obra, documentos que foram escritos por esses narradores secundários.

Creio que esses aspectos apontados já são suficientes para comprovar a minha hipótese, que poderia ser reforçada por uma leitura mais desenvolvida deste e das duas outras obras que indiquei. Se não me parece produtiva a aproximação entre Balzac e Camilo com o objetivo de ver neste um discípulo ou um continuador do romance balzaquiano em Portugal, a aproximação com Dumas, autor que em Portugal possuía o mesmo estatuto que o romancista de Ceide, mostra-se muito mais pertinente. Julgo que parece claro que algumas das posturas narrativas assumidas por Camilo nas décadas de 50 e 60 já haviam sido utilizadas por Dumas nas décadas de 30 e 40.

Penso, ainda, que essa aproximação é produtiva por vários motivos. O primeiro, de caráter mais geral, é ela indicar que, para melhor conhecermos a produção camiliana, é necessário visitar certos romances de Alexandre Dumas que são, hoje, totalmente esquecidos. Não se trata - façamos uma comparação que por seu contraste poderá mostrar melhor o que quero dizer - de recuperar romances pouco trabalhados de um Flaubert ou mesmo de um Victor Hugo, mas de um escritor considerado como popular, já em seu tempo atacado por ter criado uma fábrica de produzirfolbetins, até hoje constantemente revisitado pelos mais diferentes meios da cultura de massas - cinema, televisão e quadrinhos, por exemplo 
- e normalmente menosprezado pela crítica literária - o que pode ser comprovado pelo parco número de críticos, mesmo na França, que trabalham de forma sistemática com a sua obra. Ou seja, neste caso específico é necessário romper com um certo preconceito - que ainda existe - com a obra de Dumas, o que pode significar, se quisermos ampliar o que aqui notamos, que talvez apenas conhecendo melhor uma série de escritores que fizeram muito sucesso em Portugal na primeira metade do século xix é que poderemos melhor entender a literatura então produzida pelos autores portugueses, e não só a de Camilo.

Especificamente em relação ao próprio Camilo, julgo essa aproximação extremamente profícua, pois pode nos levar a ver na sua obra não o que falta, mas o que sobeja. O que quero indicar é que Camilo não se apropria dos procedimentos de Dumas para copiá-los, agradando assim a um público habituado a ler o autor do Conde de Monte Cristo. Ele vai além. Como não tenho como aqui desenvolver esse ponto, apresentando várias obras do autor de Anátema, centrar-me-ei em um único livro, Amor de salvação, obra que já antes analisei ${ }^{18}$.

Jacinto do Prado Coelho afirmou: "Camilo insiste sempre na veracidade das histórias que narra"19. Em Amor de salvação o narrador se apresenta como um cronista. Afirma que teria tomado conhecimento dos fatos narrados graças a um encontro, em dezembro de 1863, com o protagonista da história, Afonso de Teive. Ele já o conhecia anteriormente, mas assim que o vê não o reconhece, como ocorre na cena inicial de Gabriel Lambert. Ainda aproxima os dois romances a transcrição de cartas dos personagens - várias são as epístolas reproduzidas em Amor de salvação - e o fato de que o narrador camiliano faz inúmeras referências que indicam ser o próprio Camilo que está a narrar a história.

Se essas semelhanças, às quais poderíamos somar algumas outras, mostram que Camilo está aqui se apropriando de uma certa forma narrativa presente na produção dumasiana dos anos 30, os efeitos que decorrem dessa forma vão muito para além daqueles presentes no autor francês.

Nos três livros de Dumas a que me referi em que o narrador se apresenta como o próprio romancista - Pauline, Os irmãos corsos e Gabriel Lambert -

\footnotetext{
18 Cf. Oliveira, 2002.

19 Coelho, 1982-1983, v.2, p. 223.
} 
essa estratégia serve principalmente para reforçar a verossimilhança da obra, fazendo com que o leitor acredite estar diante de um depoimento verdadeiro. Podemos pensar que o autor está a se utilizar de uma tópica recorrente na literatura do século XIx - a do manuscrito encontrado -, deslocando a comprovação da veracidade para a sua própria experiência pessoal, e diversificando os manuscritos que encontra, que passam a ser de várias autorias, o que só viria a reforçar a imagem de que estaria a narrar algo que efetivamente aconteceu.

Camilo tira bem mais efeitos do uso desse artifício. Retomo aqui algumas conclusões a que cheguei na leitura que anteriormente apresentei sobre o livro. O narrador assume a postura de um editor que coordena os vários materiais de que se utiliza, entre os quais podemos citar as cartas de vários personagens, as memórias que tinha de Afonso de Teive antes de seu reencontro com ele e a reprodução aparentemente textual da conversa que manteve com este personagem. Mas usa esse material não apenas para reforçar a veracidade do livro, mas principalmente para criar na obra uma espécie de duplo discurso, que desestabiliza a fala de seu principal informante.

Como sabemos, Afonso de Teive, casado com Mafalda, sua prima, que considera como a mulher que o salvou, rememora na longa conversa que tem com o narrador o período em que foi amante de Teodora, mulher que o perdeu, e quase levou-o à ruína total, da qual foi salvo justamente pela fortuna de sua prima. O narrador, através de várias estratégias que já anteriormente abordamos e que não temos como aqui retomar, irá minando a fala de seu protagonista, e levará o leitor a suspeitar da forma como este reconta o seu passado. Notemos, apenas a título de exemplo, a maneira diversa como Afonso e o narrador qualificam Mafalda e Teodora.

O primeiro, num momento, afirma, referindo-se primeiro à prima, e depois à ex-amante: "Neste instante, esqueci o anjo, que me estava ali chorando, não sei mesmo se desejei que Deus o chamasse para sua pátria; e adorei o demónio, que passava lá em baixo, com o véu esvoaçante, por entre nuvens de pó, sacudidas das patas do arremessado cavalo"20. Já o narrador, no início do romance considera Mafalda "simples, modesta, e, logo à primeira vista, imprópria de novela" ${ }^{21}$, e ao

20 Castelo Branco, 1985. p. 692.

21 Castelo Branco, 1985. p. 636. 
longo da narrativa vai apresentando uma série de elogios a Teodora, como o momento em que, ao ler uma carta que ela havia enviado para Afonso, comenta: "Esta senhora tem estilo ( ). Isto sim que é mulher"22, ou no fim do livro, em que afirma: "Palmira há de ter um livro, ou eu não escrevo mais nenhum depois do teu..."23. Essas diferentes formas de encarar as duas principais mulheres da narrativa certamente fazem com que o leitor olhe para o discurso do protagonista com alguma desconfiança. O efeito dessa desconfiança é que a própria noção de veracidade acaba por ser, no livro, questionada. O fato de apresentar vários documentos e de reproduzir a fala de seu protagonista e informante não torna essa narrativa verdadeira. O que Afonso conta ao narrador, e esse reproduz para seus leitores, é uma versão do passado, motivada pelo seu presente. É tão falsa ou verdadeira como pode ser qualquer versão. É isso o que o narrador, desestabilizando o discurso que reproduz, parece querer indicar. Ou seja, através da pena genial de Camilo, em meados do século xix, estava a ocorrer neste extremo ocidental da Europa bem mais do que uma simples reprodução de modelos e esquemas do romance francês. A sua obra subverte e questiona os próprios modelos de que se utiliza.

Certamente seria necessário um trabalho muito mais detido com as obras de Camilo e de Dumas para poder ampliar e melhor fundamentar o que aqui aparece de forma apenas esquemática e sumária. Mas creio que aquilo que pudemos apontar já mostra a validade e interesse desse tipo de aproximação, e como ela pode ser produtiva para melhor entendermos certos aspectos da ficção camiliana.

22 Castelo Branco, 1985. p. 682.

23 Castelo Branco, 1985. p. 767. 


\section{BIBLIOGRAFIA}

BAPTISTA, Abel Barros (1988). Camilo e a revolução camiliana. Lisboa: Quetzal.

BRAGA, Teófilo (1892). As modernas ideias da Literatura Portuguesa. Porto: Chardron.

CASTElO BRANCO, Camilo (1984). Obras Completas vol. III. Porto: Lello \& Irmão.

(1985). Obras Completas vol. IV. Porto: Lello \& Irmão.

(1988). Obras Completas vol. VIII. Porto: Lello \& Irmão.

COELHO, Jacinto do Prado (1982-1983). Introdução ao Estudo da Novela Camiliana. Lisboa: Imprensa Nacional-Casa da Moeda. (2 vol.)

DUMAS, Alexandre (2009). Gabriel Lambert. Paris: Les livre de poche.

LOPES, Óscar (1991). Claro-escuro camiliano. Lisboa, Colóquio Letras, 119, p. 5-24, jan.-mar.

LOURENÇO, Eduardo (1978). O labirinto da saudade. Lisboa: Dom Quixote.

OliveirA, Paulo Motta (2002). "Amor de Salvação: um editor pouco confiável e seu labirinto de espelhos." In: Elza Miné; Benilde Justo Caniato. (Org.). Abrindo Caminhos. São Paulo: Área de Pós-Graduação de estudos Comparados de Literaturas de Língua Portuguesa, p. 463-472.

(2009). "Oralidade, memória e ficção na obra de Camilo Castelo Branco.” In: Irene Maria F. Blayer; Francisco Cota Fagundes. (Org.) Narrativas em metamorfose. Cuiabá: Cathedralp. 57-70.

PASCOAES, Teixeira de (1985). O Penitente. Lisboa: Assírio \& Alvim.

PIMENTEL, Alberto (1890). O Romance do Romancista. Lisboa: F. Pastor.

(1922). O romance do romancista. Lisboa: Guimarães.

REIS, Carlos, PIRES, Maria da Natividade (1999). História crítica da literatura portuguesa.

2. ed. Lisboa: Verbo.

RODRIGUES, A. A. Gonçalves (1992). A tradução em Portugal-2. Volume - 1835/1850. Lisboa: ISLA.

(1993). A tradução em Portugal - 3․ Volume - 1851/1870. Lisboa: ISLA.

(1994). A tradução em Portugal - $4^{\circ}$. Volume - 1871/1900. Lisboa: ISLA.

TENGARRINHA, José (1973). A novela e o leitor português. Lisboa: Prelo. 